\title{
Whooping Crane Dance During Migration
}

\author{
by Fred W. Lahrman; Saskatchewan Museum of Natural History
}

The spectacular display or "dance" of the Whooping Crane (Grus americana) has been well described in The Whooping Crane by Robert P. Allen 1952. National Audubon Society, Research Report No. 3). On page 175, however, Mr. Allen, owing to lack of observations, states: "Whether or not the Whoopers dance while on the spring migration route is uncertain."

While field-checking Whooping Cranes throughout the southern part of the province, Mr. Fred G. Bard and $I$ have had at various times the privilege of observing the dance of the Whooping Crane, during both the spring and fall migration period. In most cases dancing was similar to that reported by Allen, involving spread and flapping wings and erratic leaping.

On April 21, 1956, at Pasqua, at approximately 7:00 a.m. M.S.T., a pair of Whoopers with one young which we observed feeding on stubble suddenly started dancing. The adults danced very actively for several minutes and then resumed feeding. The young, however, had appeared bored with the proceedings and had kept on feeding (Blue Jay, Vol. XIV, No. 2).

On April 24, 1956 at 8:30 a.m., at Melaval, two adults and two young which were feeding on a stubble field suddenly went into a dance on top of a small knoll (see Fig. 1). One of the adults began bowing and spreading its wings, then started to leap high with flapping wings, and was then joined by the other three which leaped and flapped in a similar manner for a brief period after which all flew to a small slough where they drank water. After the two parents had left (see Blue Jay, Vol. XIV, No. 2, page 39 ) the two young were observed to dance occasionally while feeding in the field and again when at the slough.

At Govan, two adult cranes were watched at intervals for fifteen days, from October 17 to October 31, 1958. These cranes spent most of their time on the shore of Last Mountain Lake near a long sandy point. Usually during the early morning and late afternoon the cranes would fly as far as several miles to the nearby stubble fields to feed. On October 19 , late in the afternoon, the cranes went into a dance just before leaving the water to go out to feed. First they stood upright with necks stretched as high as possible and with feathers depressed, making them appear very slim. They strutted about close together, then went

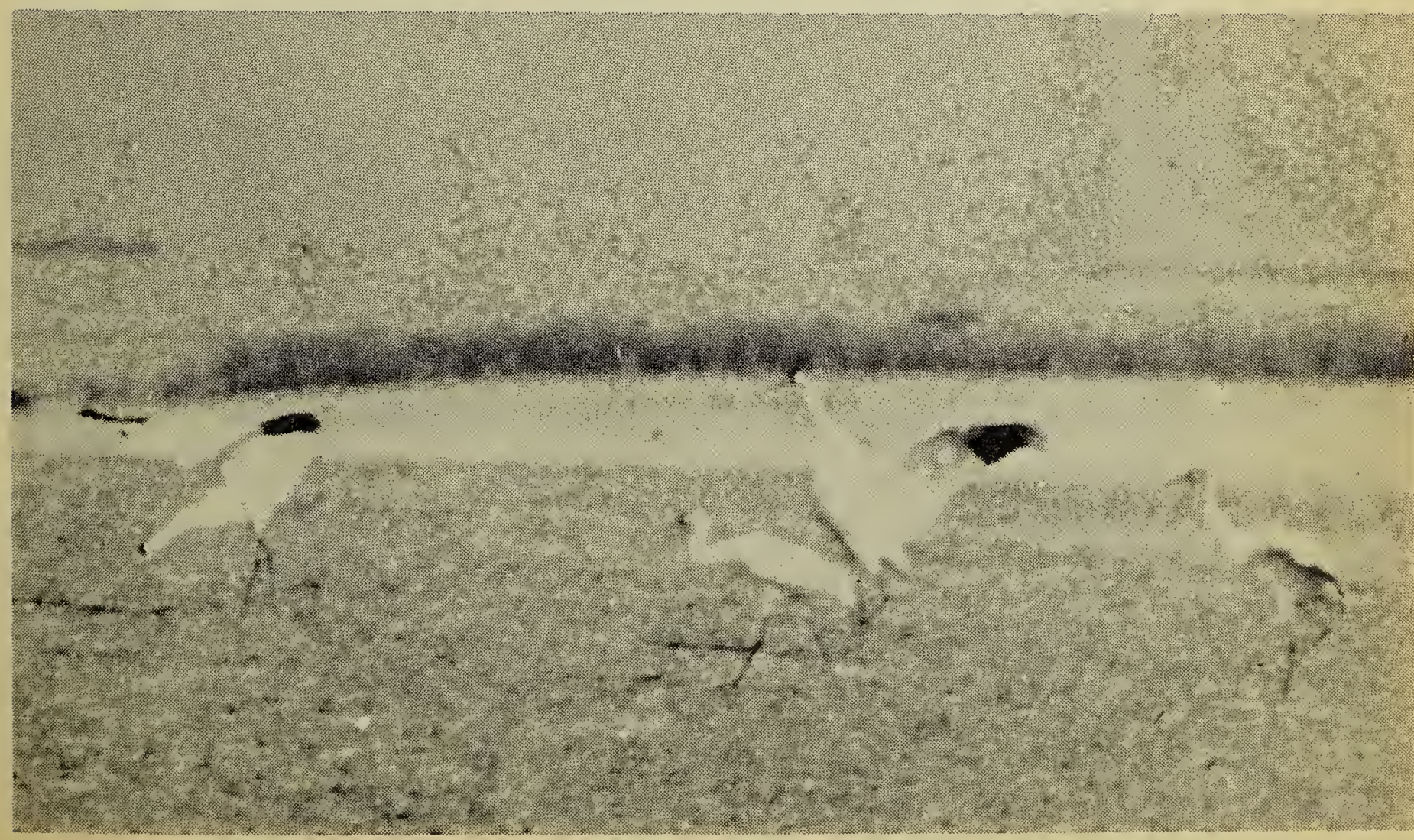

Fig. 1. Whooping Cranes at Melaval, April 24, 1956 
into the most beautiful and spectacular dance that I have ever witnessed. They ran down the beach in a southwesterly direction facing the wind, which was fairly strong, with wings spread, half flying and gliding, half skipping and jumping as they went. Occasionally they sprang very high into the air, approximately fifteen feet or more, then coasted down. Sometimes, one would stop and then the other would dance around it with wings "spread, bowing and tossing debris into the air. Finally, they both danced together again. Once they charged into a flock of ducks which were resting in shallow water near shore, causing them to fly up. The whole affair lasted approxi- mately four minutes, during which time they travelled about two hundred yards down the beach. After strutting about for a moment after the dance, they flew out to feed (4:13 p.m. M.S.T.)

On October 27, when I was photographing these same two birds again at Govan while they were feeding on the stubble at 4:30 p.m., they pcised briefly but beautifully, against the evening sky with spread wings reflecting the last rays of the setting sun (see Figs. 2, 3,4) then went into their hopping-flapping dance. One crane picked up a weed stalk and tossed it over its shoulder. The dance lasted for only about a minute, then they resumed feeding.

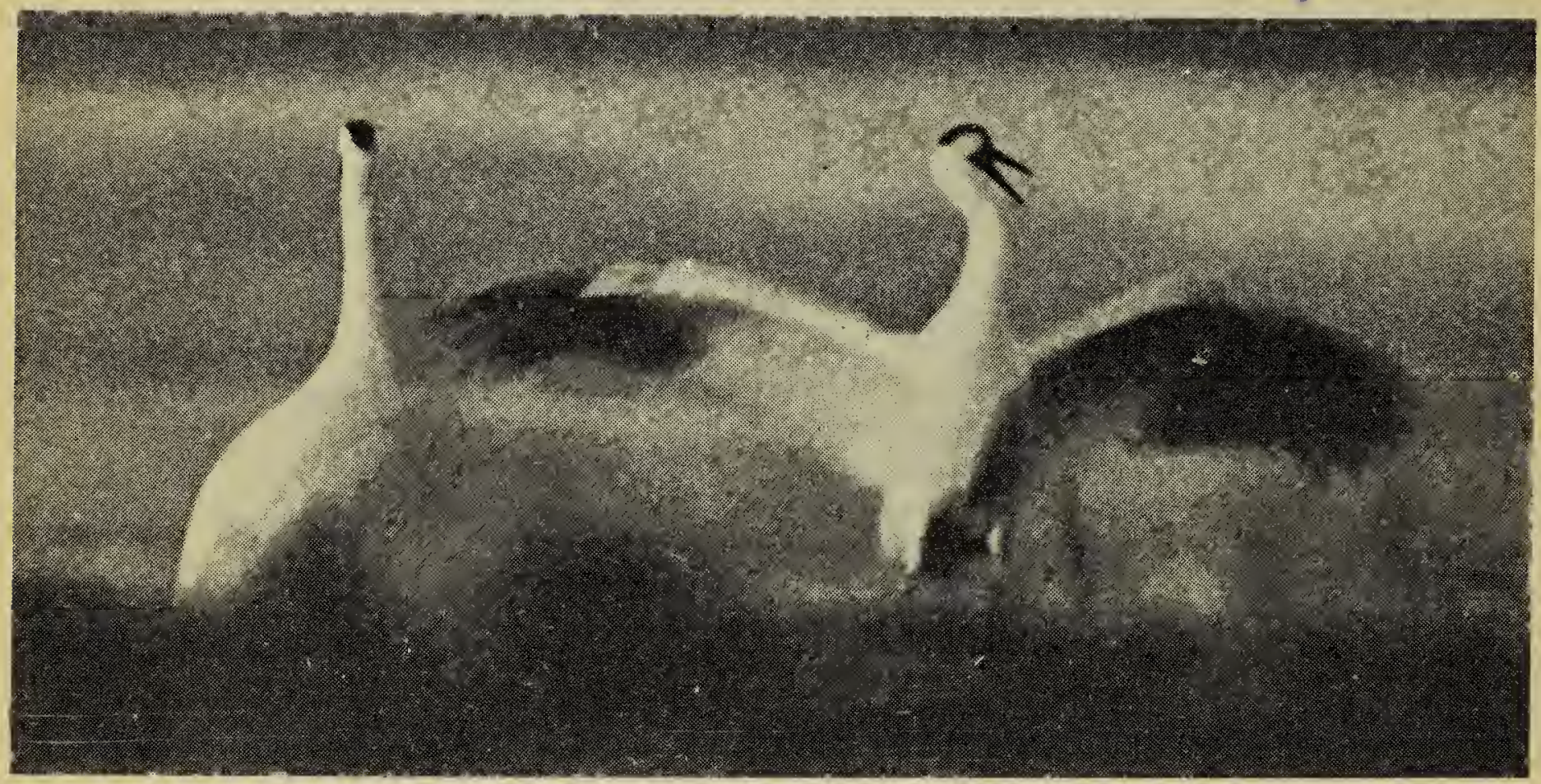

Fig. 2: The Whooping Crane dance, Govan, Sask., Oct. 27, 1958. The crane on the right "picked up a weed stalk and tossed it over its shoulder."

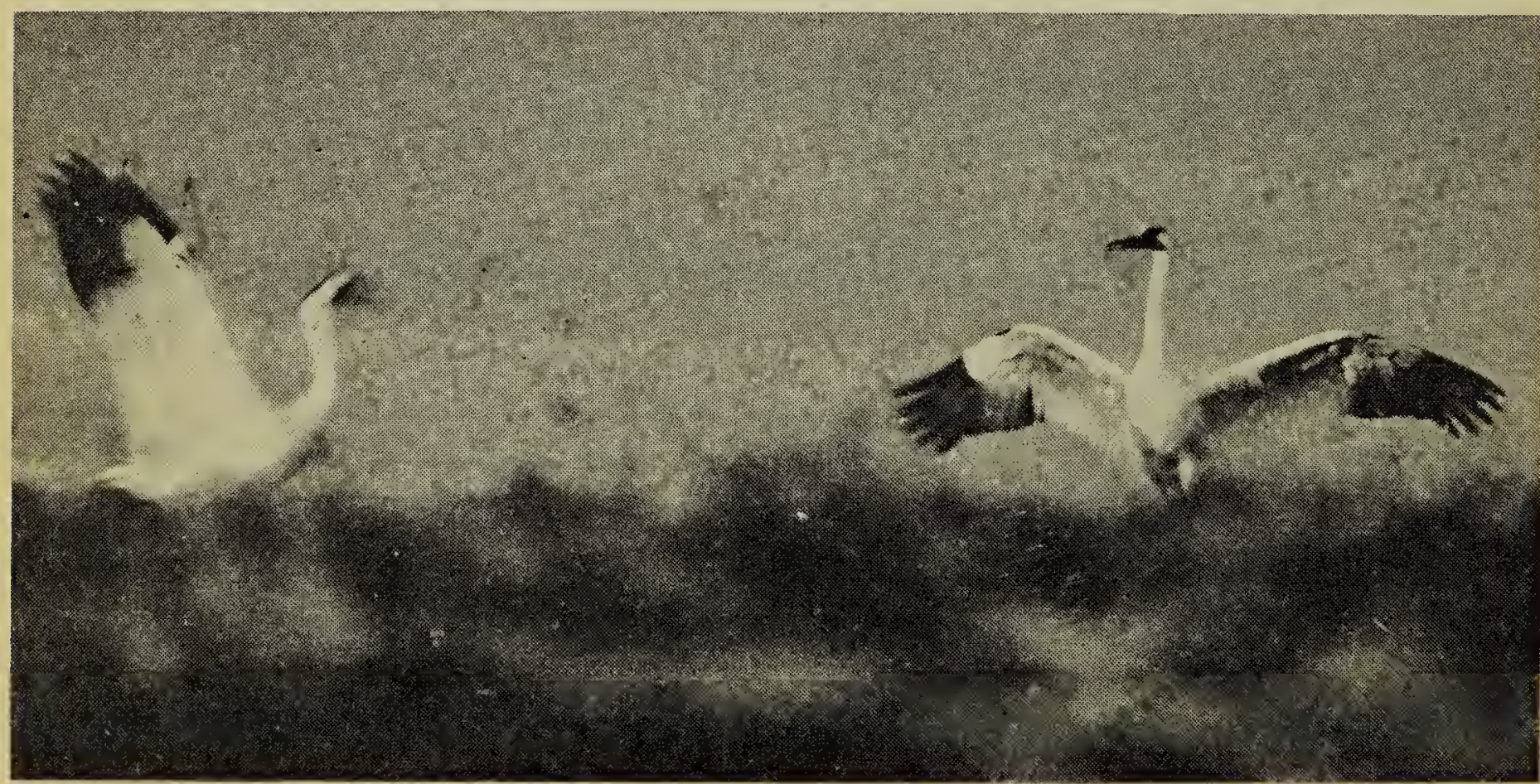

Fig. 3: They posed briefly "with spread wings reflecting the last rays of the setting sun." 


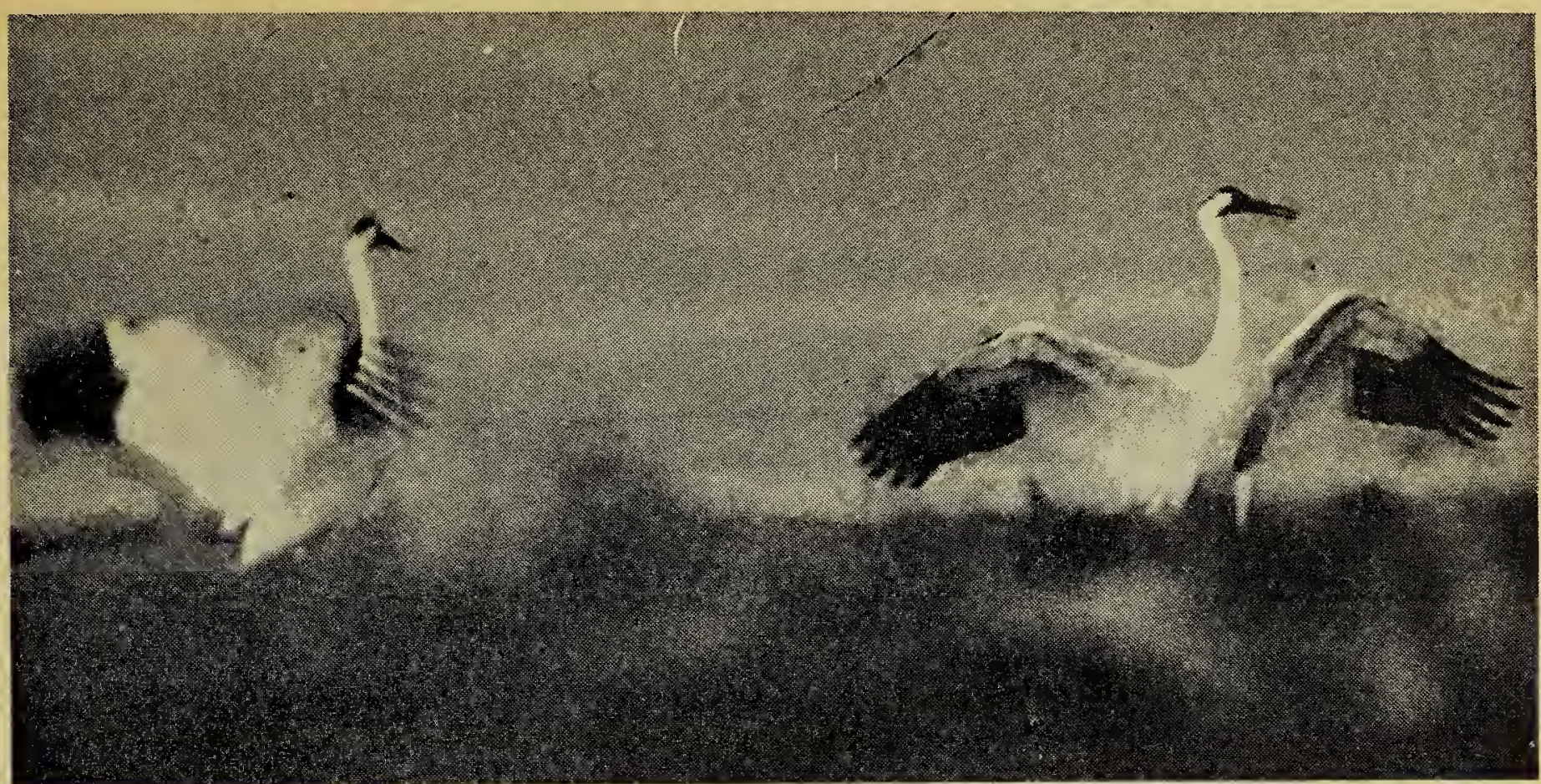

Fig. 4: Then "went into their hopping-flapping dance." Photo from kodachrome (500 $\mathrm{mm}$. telephoto lens, f. 5.6, $1 / 15$ sec.). A.11 photos by F. W. Lahrman.

\section{A. C. Bent's 1917 Trip to Saskatchewan}

by Stuart Houston, Yorkton, Sask.

The "In Memoriam" tribute to Arthur Cleveland Bent by Wendell Taber, published in The Auk of October, 1955, included a listing of Bent's field trips. Bent's visits to Saskatchewan in 1905 and 1906 are well known, and were fully documented in his paper on the "Summer Birds of Southwestern Saskatchewan" which appeared in The Auk in October 1907 and January 1908. References to his experiences on this trip also appear throughout his Life Histories of North American Birds. However, Taber also listed another trip to Saskatchewan: "1917. Northern Saskatchewan alone." This latter item caught my fancy as I could find nothing published on the results of this trip.

The mystery has been resolved by Mrs. Madeleine V. Bent, his widow. She wrote on Sept. 29, 1958: "Mr. Bent actually accomplished no field work in 1917 as he was ill during his entire stay, with a severe sinus disturbance. He remained some time there, hoping to throw it off. However, he grew worse and finally returned, and never found the opportunity to go again."

Mrs. Bent was later able to find two letters written by $\mathrm{Mr}$. Bent during the trip. The first, dated May 24, 1917: "Wynyard, Sask. I have changed my mind and am not going to the place I planned, but shall start tomorrow morning in an automobile for a 25 mile ride up around the
Lake to Quill Lake town, where I learn there is a good hotel. I shall size up the country on the way and if I see any place on the way that looks good to me, I may arrange to stop there. You see I do not know anything about this country and cannot find out much about it, so I shall look it over. If I do not find anything better than I have seen so far, I shall move on farther west." The second letter, dated May 30, reads: "Prince Albert, Sask. I arrived here last night and have been out all day exploring. I find I can stay at a hotel here and go out early in the morning, and back late at night to various places I want to explore. So far I have found very little that interests me, and the country does not look suitable for the birds that I want to find. I may find some better country tomorrow, or next day but if not I shall "beat it" either back to Quill Lake for a few days or back home."

Mrs. Bent commented in a letter to me on Nov. 20,1958 that "Mr. Bent must have taken ill soon after this. Feeling discouraged, he gave up and came home." We were thus deprived of what would likely have been valuable contributions to our knowledge of Saskatchewan ornithology.

I wish to thank Wendell Taber, F. Seymour Hersey, and particularly Mirs. Madeleine V. Bent, for the assistance they have given me. 